\title{
Rutile occurrence and trace element behavior in medium-grade metasedimentary rocks: example from the Erzgebirge, Germany
}

\author{
George Luiz Luvizotto $•$ Thomas Zack • Silke Triebold • \\ Hilmar von Eynatten
}

Received: 29 January 2009 / Accepted: 23 October 2009/Published online: 13 November 2009

(C) The Author(s) 2009. This article is published with open access at Springerlink.com

\begin{abstract}
Metamorphic textures in medium-grade ( 500 $\left.550^{\circ} \mathrm{C}\right)$ metasedimentary rocks from the Erzgebirge give evidence of prograde rutile crystallization from ilmenite. Newly-crystallized grains occur as rutile-rich polycrystalline aggregates that pseudomorph the shape of the ilmenites. In-situ trace element data (EMP and SIMS) show that rutiles from the higher-grade samples record large scatter in $\mathrm{Nb}$ content and have $\mathrm{Nb} / \mathrm{Ti}$ ratios higher than
\end{abstract}

Editorial handling: F. Gaidies and T. John

\author{
G. L. Luvizotto $(\triangle) \cdot$ T. Zack \\ Institut für Geowissenschaften, Mineralogie, \\ Universität Heidelberg, \\ Im Neuenheimer Feld 236, \\ 69120 Heidelberg, Germany \\ e-mail: george.luvizotto@mpic.de \\ T. Zack \\ e-mail: zack@uni-mainz.de \\ G. L. Luvizotto \\ Geochemie, Max-Planck-Institute für Chemie, \\ Joh.-Joachim-Becher-Weg 27, \\ 55128 Mainz, Germany \\ T. Zack \\ Institut für Geowissenschaften, Universität Mainz, \\ Becher Weg 21, \\ 55128 Mainz, Germany \\ S. Triebold $\cdot H$. von Eynatten \\ Sedimentologie und Umweltgeologie, \\ Geowissenschaftliches Zentrum, Universität Göttingen (GZG), \\ Goldschmidtstr. 3, \\ 37077 Göttingen, Germany \\ S. Triebold \\ e-mail: striebo@gwdg.de \\ H. von Eynatten \\ e-mail: hilmar.von.eynatten@geo.uni-goettingen.de
}

coexisting ilmenite. This behavior can be predicted using prograde rutile crystallization from ilmenite and indicates that rutiles are reequilibrating their chemistry with remaining ilmenites. On the contrary, rutiles from the lowest grade samples $\left(\sim 480^{\circ} \mathrm{C}\right)$ have $\mathrm{Nb} / \mathrm{Ti}$ ratios that are similar to the ones in ilmenite. Hence, rutiles from these samples did not equilibrate their chemistry with remaining ilmenites. Our data suggest that temperature may be one of the main factors determining whether or not the elements are able to diffuse between the phases and, therefore, reequilibrate. Newly-crystallized rutiles yield temperatures (from $\sim 500$ to $630^{\circ} \mathrm{C}, \mathrm{Zr}$-in-rutile thermometry) that are in agreement with the metamorphic conditions previously determined for the studied rocks. In quartzites from the medium-grade domain $\left(\sim 530^{\circ} \mathrm{C}\right)$, inherited detrital rutile grains are detected. They are identified by their distinct chemical composition (high $\mathrm{Zr}$ and $\mathrm{Nb}$ contents) and textures (single grains surrounded by fine grained ilmenites). Preliminary calculation, based on grain size distribution of rutile in medium-grade metapelites and quartzites that occur in the studied area, show that rutiles derived from quartzites can be anticipated to dominate the detrital rutile population, even if quartzites are a minor component of the exposure.

\section{Introduction}

Several studies have recently promoted the application of in-situ trace element analyses of accessory minerals as a tool to monitor geochemical processes in metamorphic and igneous rocks. This is a reflection of the continuous development of several in-situ analytical techniques (i.e., higher spatial resolution and lower detection limits) and the fact that accessory minerals are frequently the main carrier of trace elements used as tracer of geochemical processes 
(e.g., $\mathrm{Zr}$ in zircon, $\mathrm{Ti}$ in rutile, rare earth elements in monazite and xenotime).

Rutile is one of the major Ti-phases, frequently occurring as an accessory mineral in diverse metamorphic and igneous rocks, siliciclastic sediments, placer deposits and hydrothermal ore deposits. As it incorporates several highly-charged trace elements (e.g., Ti, $\mathrm{Zr}, \mathrm{Nb}, \mathrm{Ta}, \mathrm{Sn}$, $\mathrm{Sb}, \mathrm{W}, \mathrm{V}, \mathrm{Cr}$ and Mo, see summary in Zack et al. 2002) rutile has successfully been applied as a tool to monitor geochemical processes such as subduction-zone metasomatism, magma evolution and element cycling (e.g. Saunders et al. 1980; McDonough 1991; Brenan et al. 1994; Stalder et al. 1998; Münker 1998; Foley et al. 2000; Rudnick et al. 2000; Klemme et al. 2005). With the calibration of the Zrin-rutile thermometer (Zack et al. 2004b; Watson et al. 2006; Tomkins et al. 2007) rutile has become an important tool for assessing metamorphic temperatures, especially in eclogite- and granulite-facies rocks (Zack and Luvizotto 2006; Spear et al. 2006; Harley 2008; Luvizotto and Zack 2009). In provenance studies, $\mathrm{Nb}$ and $\mathrm{Cr}$ systematics in rutile can be used to distinguish pelitic from mafic protoliths (Zack et al. 2004a; Stendal et al. 2006; Triebold et al. 2007; Meinhold et al. 2008).

Luvizotto and Zack (2009) investigated the behavior of trace elements during prograde (amphibolite- to granulitefacies transition) rutile crystallization from a pre-existing Ti-phase in the amphibolite- to granulite-facies transition. The authors observe that $\mathrm{Nb}$ concentrations in rutile from lowest grade samples $\left(<850^{\circ} \mathrm{C}\right)$ show a larger spread when compared to those from higher grades (up to $930^{\circ} \mathrm{C}$ ). This pattern can be predicted using prograde rutile growth formed from biotite breakdown. Their results support that elements that are usually interpreted to be immobile at whole rock scale (e.g., $\mathrm{Zr}, \mathrm{Nb}$ and $\mathrm{Ti}$ ) were able to diffuse and reequilibrate between rutile and biotite under granulitefacies conditions.

In the present study we investigate whether or not equilibrium partitioning of trace elements is operating between rutile and other minerals during metamorphism in lower-grade conditions. Medium-grade metasedimentary rocks from the Erzgebirge display textures that support prograde rutile crystallization associated with ilmenite breakdown. These textures are similar to the ones described by Luvizotto and Zack (2009), since in either case rutile is forming from pre-existing Ti-bearing phases (high-Ti biotite and ilmenite).

In this study we also address an issue highlighted in a companion study by Triebold et al. (2007). Several rutiles from present-day drainage sediments sampled within the lowest-grade domain (greenschist-facies) of the studied area record high temperatures (up to $1000^{\circ} \mathrm{C}$ ). These rutiles are interpreted as inherited detrital grains, preserved in the metasedimentary rocks of the studied area (source for the present-day sediments). High temperatures are attributed to a former metamorphic cycle. In order to shed more light on the occurrence of such inherited grains we discuss the temperature records in rutiles from greenschist-facies rocks. Additionally, we briefly investigate which rock type is capable of delivering the highest amount of rutile to sediments derived from low- to medium-grade metasedimentary rocks, taking into account the occurrence of inherited rutiles as discussed above.

\section{Geological setting and studied samples}

The Erzgebirge is situated at the northwestern border of the Bohemian Massif and is part of the metamorphic basement of the Mid-European Variscides (Fig. 1). It is characterized by a large-scale antiformal structure consisting of five tectonometamorphic units (Willner et al. 1997; Rötzler et al. 1998). From the base to the top these units are: Red and Grey Gneisses (RGG); Gneiss/Eclogite Unit (GEU); Mica schist/Eclogite Unit (MEU); Garnet-Phyllite Unit (GPU); and Phyllite Unit (PU). The tectonometamorphic stacking is interpreted as a result of continent-continent collision processes during the Variscan Orogeny (e.g., Willner et al. 1997; Rötzler et al. 1998; Mingram 1998). Geochemical discriminations suggest that the protoliths of all metamorphic units are similar (mature sediments, exposed to prolonged tropical weathering and extensive reworking), leading to the conclusion that they represent a repetition of metasedimentary sequences (Mingram 1998). Peak pressure $(P)$ and temperature $(T)$ conditions published for the western part of the Erzgebirge are presented in Fig. 1 (references are given in the figure caption) and can be summarized as follows: PU, $400^{\circ} \mathrm{C}$ and $2 \mathrm{kbar}$; GPU, $480^{\circ} \mathrm{C}$ and 6 to $9 \mathrm{kbar}$; MEU, 500 to $550^{\circ} \mathrm{C}$ and 7 to $12 \mathrm{kbar}$; GEU, 100 to $800^{\circ} \mathrm{C}$ and 12 to $24 \mathrm{kbar}$; RGG, 600 to $650^{\circ} \mathrm{C}$, and 6 to $8 \mathrm{kbar}$.

The present study focuses on the GPU, MEU and GEU in the western part of the Erzgebirge, more specifically, on metasedimentary rocks from the GPU and MEU. Clockwise $P-T$ paths are documented for the Western Erzgebirge. For the GEU, decompression at very high temperatures is accompanied by cooling. $P-T$ paths for the MEU and GPU indicate heating during early pressure release. $P-T$ paths of these three units converge at pressures corresponding to $0.6-0.8 \mathrm{GPa}$, suggesting that these units were juxtaposed at the corresponding depths (Willner et al. 1997; Rötzler et al. 1998). Metasediments from the GPU are characterized by the occurrence of graphite phyllites, garnet- and albite-bearing phyllites, feldspar-free, chloritoid-bearing phyllites, quartzites, marbles and metatuffites. Garnet-free phyllites are the most common rocks in the GPU. Metasediments from the MEU are characterized by the occurrence of garnet-bearing mica schists (that may 


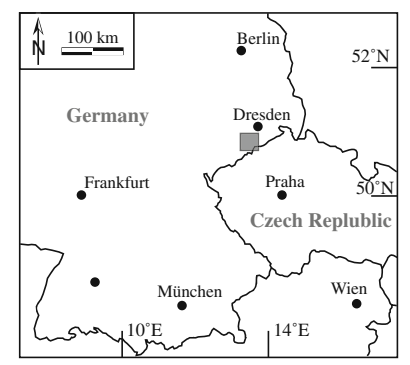

Legend

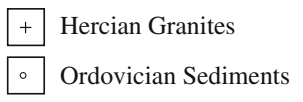

Tectonometamorphic Units

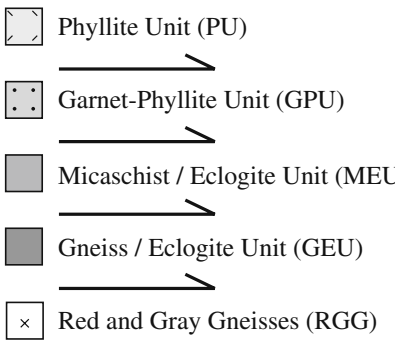

Sample Location

$\oplus$ EGB-R\#

$\otimes$ Samples from Mingram (1998)

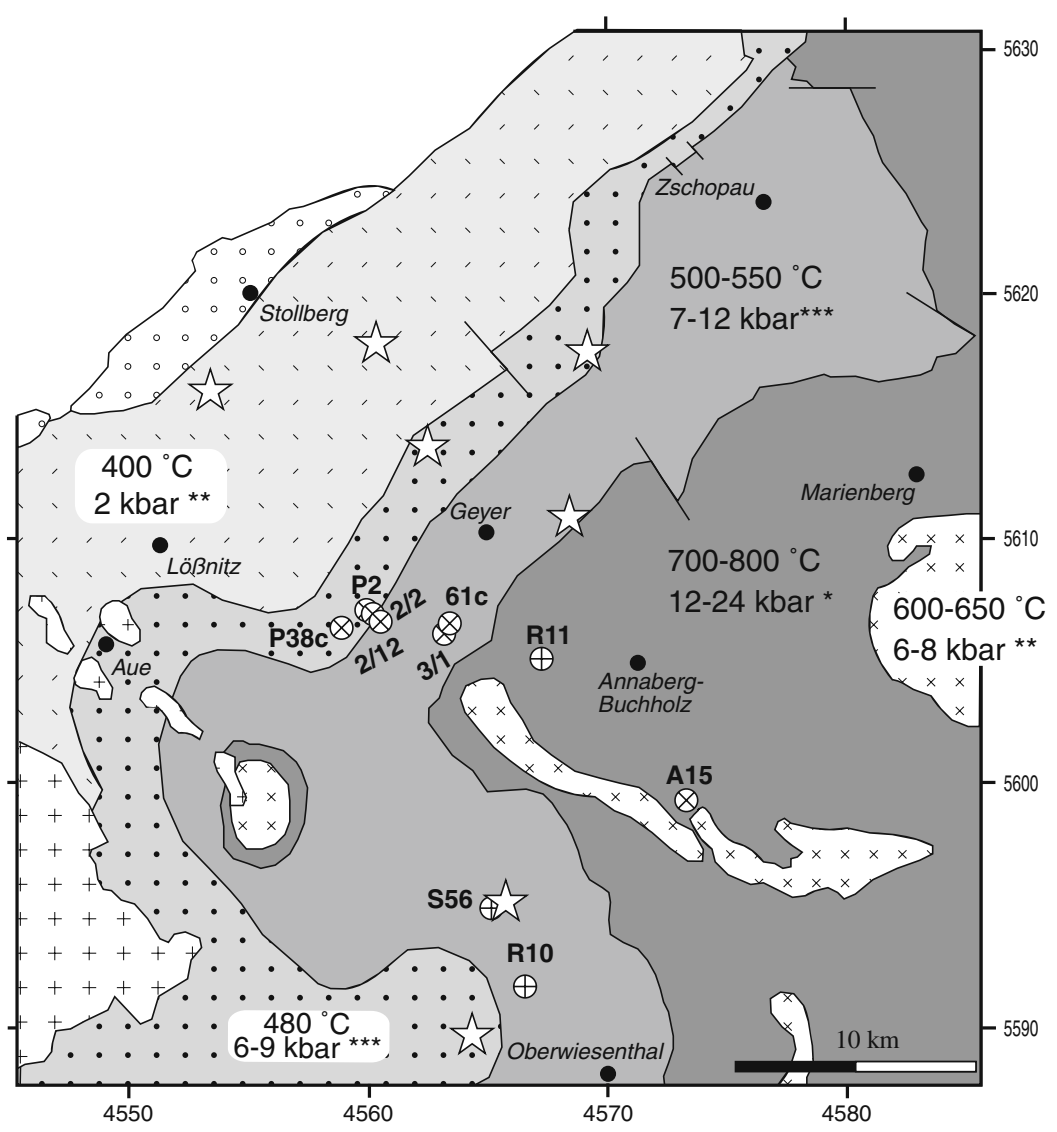

areas where relic rutiles (Zr-in-rutile temperatures strongly exceeding peak metamorphic temperature reached in these tectonometamorphic units) were found by Triebold et al. (2007)

Heidelberg with a CAMECA SX51 equipped with 5 WDS detectors. The beam was set to $20 \mathrm{kV}$ and $100 \mathrm{nA}$ and analyses followed the method outlined by Luvizotto et al. (2009). The following elements were analyzed: $\mathrm{Si}, \mathrm{Ti}, \mathrm{V}, \mathrm{Cr}, \mathrm{Fe}, \mathrm{Zr}, \mathrm{Nb}$ and $\mathrm{W}$. With this setup, the detection limits are $220 \mathrm{ppm}$ for $\mathrm{V}, 50 \mathrm{ppm}$ for $\mathrm{Cr}, 40 \mathrm{ppm}$ for $\mathrm{Fe}$ and $\mathrm{Zr}, 60 \mathrm{ppm}$ for $\mathrm{Nb}$ and $350 \mathrm{ppm}$ for $\mathrm{W}$. To control zero-concentration peak intensities and instrument drift, every block of ten analyses of unknown was bracketed by two analyses of synthetic rutile with nominal zero-concentration of trace elements. Concentrations of $\mathrm{Si}$ were used to detect and avoid contamination associated with submicroscopic zircon inclusions (according to the method outlined by Zack et al. 2004b). Rutile measurements with apparent Si concentrations higher than $300 \mathrm{ppm}$ that showed unusually high $\mathrm{Zr}$ contents were excluded from the data set (same procedure applied to SIMS analyses). EMP beam diameter was set to $5 \mu \mathrm{m}$. However, due to secondary fluorescence the minimum grain size for obtaining reliable analyses (i.e., analyses with Si content $<300 \mathrm{ppm}$ ) was $\sim 20 \mu \mathrm{m}$. For small (ca. $20 \mu \mathrm{m}$ ) rutile grains and for rutile aggregates, measurements with $\mathrm{Si}$ content above $300 \mathrm{ppm}$ and $\mathrm{Zr}$ concentrations similar to
Electron microprobe analyses of rutile and ilmenite were carried out at the Institut für Geowissenschaften, Universität 


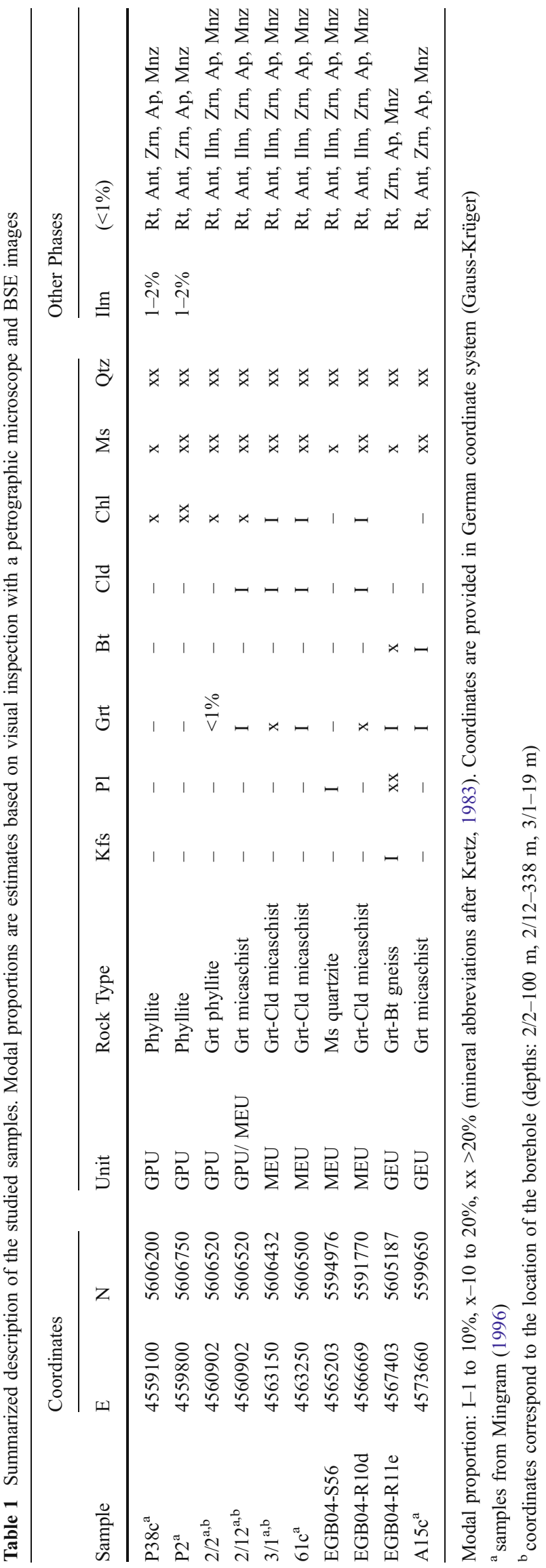

rutiles with low $\mathrm{Si}$ contents were not excluded (high $\mathrm{Si}$ values were interpreted as secondary fluorescence from silicates).

Secondary ion mass spectrometry (SIMS)

SIMS measurements of rutile and ilmenite were performed at the Institut für Geowissenschaften, Universität Heidelberg with a CAMECA ims $3 \mathrm{f}$. Analyses were carried out using a $14.5 \mathrm{keV} / 10-20 \mathrm{nA}^{16} \mathrm{O}^{-}$primary ion beam, which resulted in spot sizes of $20-30 \mu \mathrm{m}$. By using a field aperture the effective spot size was reduced to $12 \mu \mathrm{m}$. With this setup, the smallest grain size for obtaining contamination free analyses was ca. 20 to $30 \mu \mathrm{m}$. Positive secondary ions were nominally accelerated to $4.5 \mathrm{keV}$ (energy window set to $\pm 20 \mathrm{eV}$ ) and the energy filtering technique was used with an offset of $90 \mathrm{eV}$ at mass resolution $\mathrm{m} / \Delta \mathrm{m}$ $(10 \%)$ of 370 . Count rates were normalized to ${ }^{47} \mathrm{Ti}$. $\mathrm{TiO}_{2}$ in rutile is assumed to be $100 \mathrm{wt} . \%$, which introduces an error of $<1 \%$, as elements other than $\mathrm{Ti}$ and $\mathrm{O}$ occur only in minor amounts in the studied rutiles. In ilmenite, the Ti concentration was based on the values obtained by EMP. The following isotopes were analyzed: ${ }^{27} \mathrm{Al},{ }^{30} \mathrm{Si},{ }^{47} \mathrm{Ti}$, ${ }^{90} \mathrm{Zr},{ }^{93} \mathrm{Nb},{ }^{118} \mathrm{Sn},{ }^{120} \mathrm{Sn},{ }^{121} \mathrm{Sb},{ }^{123} \mathrm{Sb},{ }^{178} \mathrm{Hf},{ }^{181} \mathrm{Ta},{ }^{184} \mathrm{~W}$, ${ }^{186} \mathrm{~W},{ }^{232} \mathrm{Th},{ }^{238} \mathrm{U}$. Concentrations were calculated based on relative sensitivity factors (RSF) determined using a set of rutile reference materials presented by Luvizotto et al. (2009). Since Th concentrations are not available for the reference materials used here, no reliable RSF can be calculated for Th. However, intensity ratios obtained for the studied rutiles suggest that Th concentrations are extremely low (below the $0.1 \mathrm{ppm}$ level when using RSF of U).

Micro-Raman spectroscopy

Laser micro-Raman spectroscopy was applied to selected grains in order to identify the $\mathrm{TiO}_{2}$ structure type. Raman spectra were obtained using a Horiba Jobin Yvon Labram HR-UV 800 (equipped with a Peltier-cooled CCD detector) at the Geowissenschaftliches Zentrum, Universität Göttingen. Analyses were carried out using $633 \mathrm{~nm}$ laser excitation, $20 \mathrm{~mW}$ laser power, $1200 \mathrm{l} / \mathrm{mm}$ grating and a Peltier-cooled CCD detector.

\section{Results}

Textural evidence for rutile growth in medium-grade metapelitic rocks

In GPU rocks rutiles occur as polycrystalline aggregates, which are characterized by a fine-grained intergrowth of rutile and chlorite that mimic the shape of ilmenites that 
coexist in the rock. Similar textures, although with a higher rutile/ilmenite ratio, can still be found in some metasedimentary rocks from the MEU (Fig. 2). These textures indicate rutile grow from ilmenite breakdown (Fig. 2). As the content of Ti is higher in rutile than in ilmenite (100 wt.\% $\mathrm{TiO}_{2}$ in rutile vs. $\sim 53 \mathrm{wt} . \% \mathrm{TiO}_{2}$ in ilmenite), the physical volume once occupied by ilmenite is not entirely filled by rutile (Fig. 2). The Fe released from the breakdown of ilmenite is used, together with the elements available in matrix minerals (quartz and phyllosilicates), to crystallize chlorite according to the simplified metamorphic reaction: $\mathrm{Ilm}+$ silicates $+\mathrm{H}_{2} \mathrm{O} \rightarrow \mathrm{Rt}+\mathrm{Chl}$ (mineral abbreviations after Kretz 1983). The BSE images presented in Fig. 2 are arranged according to an increasing rutile/ilmenite ratio, which we interpret to represent the prograde evolution of the textures. In Figs. 2a and 2b only minor amounts of rutile are present and ilmenite grains still preserve their euhedral/ subhedral elongated (lath) habit. Figs. 2c to 2e show more evolved stages of the texture. The occurrence of a large polycrystalline rutile aggregate only a few micrometers apart
Fig. 2 BSE images exemplifying the textures observed in metasedimentary rocks from the GPU and MEU. The images are arranged in order of increasing rutile/ilmenite ratio. Numbers given in the figures correspond to $\mathrm{Nb}$ concentrations (in $\mathrm{ppm}$ ) and $\mathrm{Nb} / \mathrm{Ti}$ ratios. All scale bars represent $100 \mu \mathrm{m}$. See text for further information. Samples: A, $\mathrm{B}$ and D-P38c; C and E-P2; G2/12; H-2/2
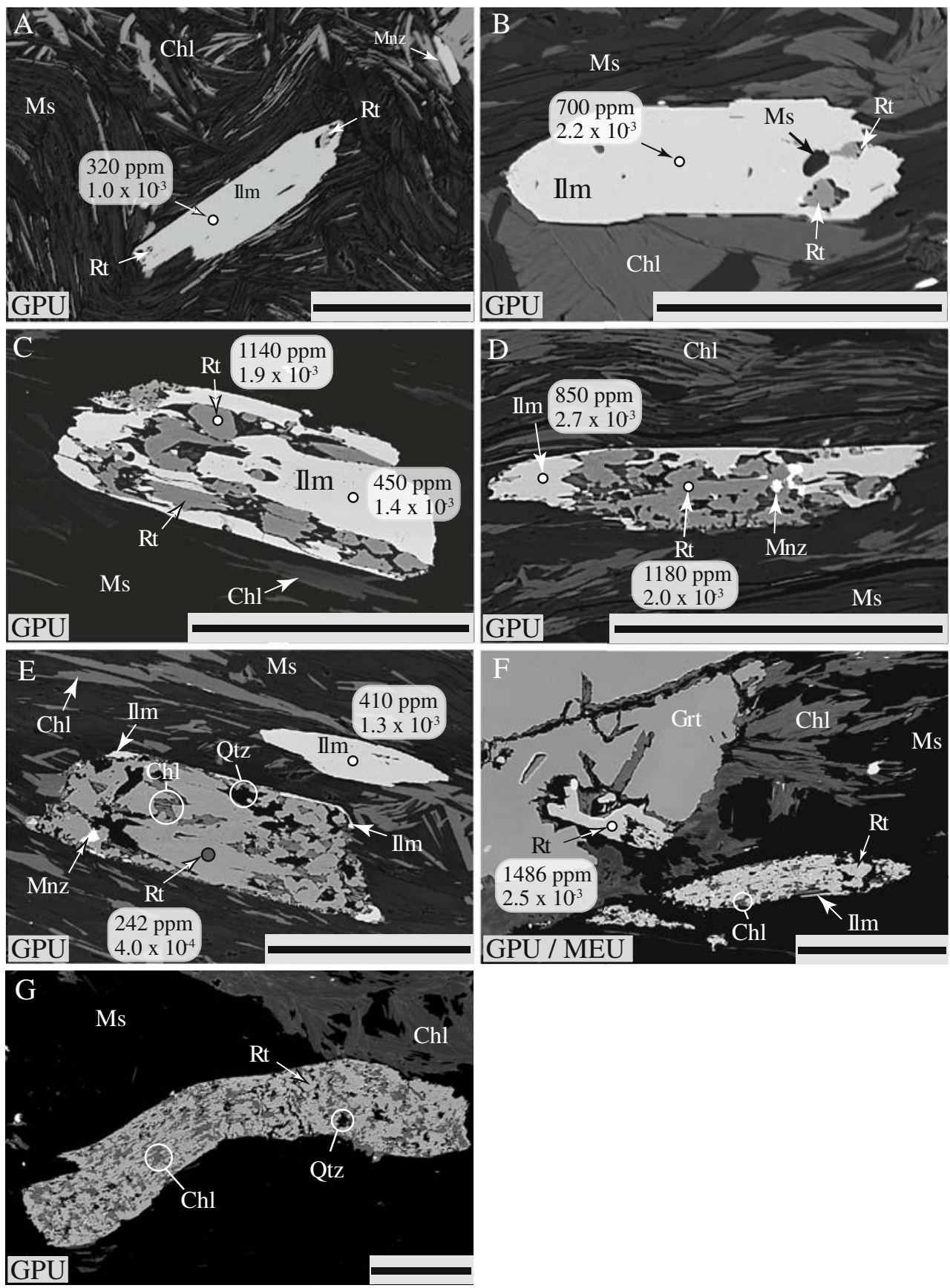
from an apparently unreacted ilmenite (representing different evolutional stages of the reaction) indicate the small size of the reaction domain (Fig. 2e). In Figs. $2 \mathrm{f}$ and $2 \mathrm{~g}$ ilmenite is virtually absent. However, rutiles still occur as aggregates that have the elongated shape inherited from ilmenites. Rutiles are often present as inclusions in garnet bearing rocks from the MEU (Fig. 2f).

An important exception to the samples descrided above is the only analyzed quartzite (EGB04-S56, MEU) in this study. This sample contains some large single crystals of rutile that are surrounded by finegrained ilmenite (Fig. 3). These rutiles do not have the typical lath shape of the newly-grown rutiles. We interpret these grains as inherited detrital rutiles that are still preserved in the quartzite.

Metapelitic rocks from the GEU are ilmenite-free. In these rocks rutiles show no traces of the texture described above and have a rounded shape (Fig. 4).

Identification of $\mathrm{TiO}_{2}$ polymorphs

Rutile was identified by Raman bands at 242, 449 and $614 \mathrm{~cm}^{-1}$ (for a compilation of Raman bands for Ti polymorphs see Meinhold et al. 2008) and anatase was identified by Raman bands at 146, 199, 400, 517 and $642 \mathrm{~cm}^{-1}$ (Fig. 5). Brookite was not found in the studied samples. In the investigated rocks rutile is brownish/reddish under the optical microscope (transmitted light) while anatase is light-brown to colorless. Some Ti-oxides displayed cathodoluminescence (CL) emission during EMP measurements (visible as a bright spot when the mineral was under the focused electron beam). All of these grains were identified as anatase by Raman. BSE images of coexisting Ti-polymorphs show that rutile is brighter than anatase in the studied samples (Fig. 5). All these characteristics were used as identification criteria.

The current work focuses only on the textural and chemical relationships between rutile and ilmenite. A more detailed work on the identification and chemical composition of $\mathrm{TiO}_{2}$ polymorphs in Erzgebirge rocks and presentday drainage sediments will be published by Triebold et al. (in prep.).

Fig. 3 BSE images of rutiles interpreted as inherited detrital grains in the quartzite. Concentrations (in ppm) stand for $\mathrm{Nb}$ and $\mathrm{Zr}$ (in italic). Pure numbers represent $\mathrm{Nb} / \mathrm{Ti}$ ratios. Scale bars represent $100 \mu \mathrm{m}$. bd below detection limit (EMP)
Comparison between $\mathrm{Nb}$ concentrations in rutile and ilmenite

Figure 6 summarizes $\mathrm{Nb}$ concentrations obtained for rutiles and ilmenites (for a complete data set, please refer to Appendix A, Table 3). $\mathrm{Nb}$ contents in ilmenite are rather constant when compared to those in rutile, with average concentration of ca. $500 \mathrm{ppm}$ in almost all samples. In contrast, $\mathrm{Nb}$ concentrations in rutile are characterized by three distinct patterns, closely connected to the metamorphic unit from which they derive. Rutiles from the GPU have lower $\mathrm{Nb}$ contents (max. concentration of $1330 \mathrm{ppm}$ ) than those from MEU and GEU (total of 11 grains with concentrations higher than $2500 \mathrm{ppm}$; max. concentration up to $9500 \mathrm{ppm}$ ). Moreover, their $\mathrm{Nb} / \mathrm{Ti}$ ratios are comparable with values obtained for ilmenites from the same samples. Rutiles from the MEU have higher $\mathrm{Nb}$ contents and display larger spread in $\mathrm{Nb}$ concentrations with $\mathrm{Nb} / \mathrm{Ti}$ ratios spanning from values as low as the ones obtained for the ilmenites to values significantly higher. Rutiles from the GEU show a narrow spread in $\mathrm{Nb}$ concentration. These samples are ilmenite-free and, therefore, no direct comparison can be made.

\section{Zirconium concentrations in rutile}

For each analysis, a Zr-in-rutile temperature (Fig. 7 and Appendix A, Table 3) was calculated (calibration of Tomkins et al. (2007) at pressure conditions defined in Fig. 1 for each metamorphic zone). $\mathrm{Zr}$ contents in all rutiles from the GPU are below the EMP detection limit $\left(<40 \mathrm{ppm}\right.$, corresponding to ca. $\left.<500^{\circ} \mathrm{C}\right)$ and are in agreement with peak temperatures reported for this unit $\left(<500^{\circ} \mathrm{C}\right.$, Rötzler et al. 1998). A SIMS measurement of $46 \mathrm{ppm}$ of $\mathrm{Zr}$ obtained for sample P2 match the EMP data. About half of the rutiles analyzed from the MEU (15 out of 28) have $\mathrm{Zr}$ contents below the EMP detection limit. The other grains have higher $\mathrm{Zr}$ contents $(60-80 \mathrm{ppm})$, which are confirmed through EMP as well as SIMS analyses. These results are in agreement with concentrations backcalculated from peak metamorphic conditions known for this area $\left(500-550^{\circ} \mathrm{C}, 0.7-12\right.$. GPa). The only exception is
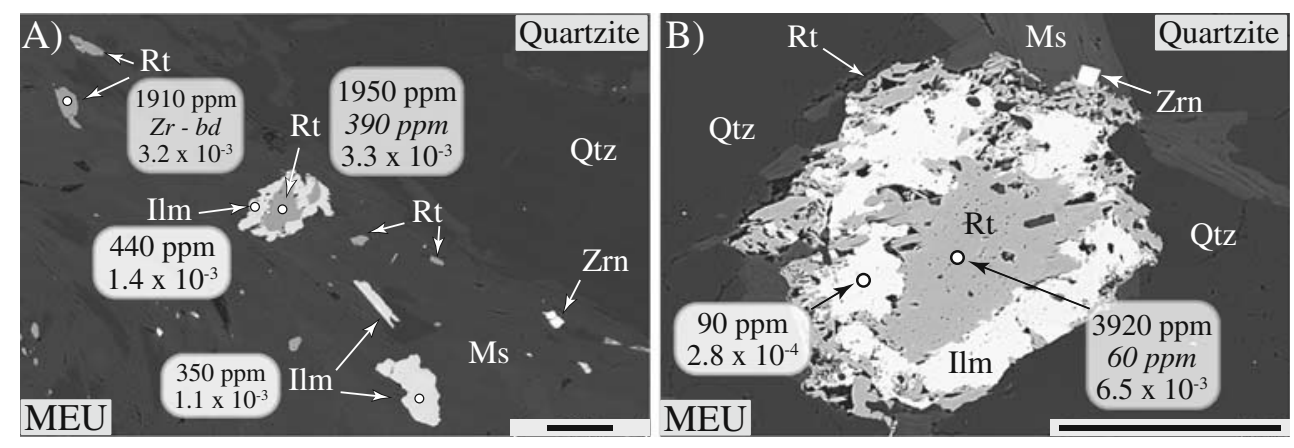
Fig. 4 BSE images exemplifying rutiles occurring in metasedimentary rocks from the GEU. Fe-Sulf-Fe sulfide
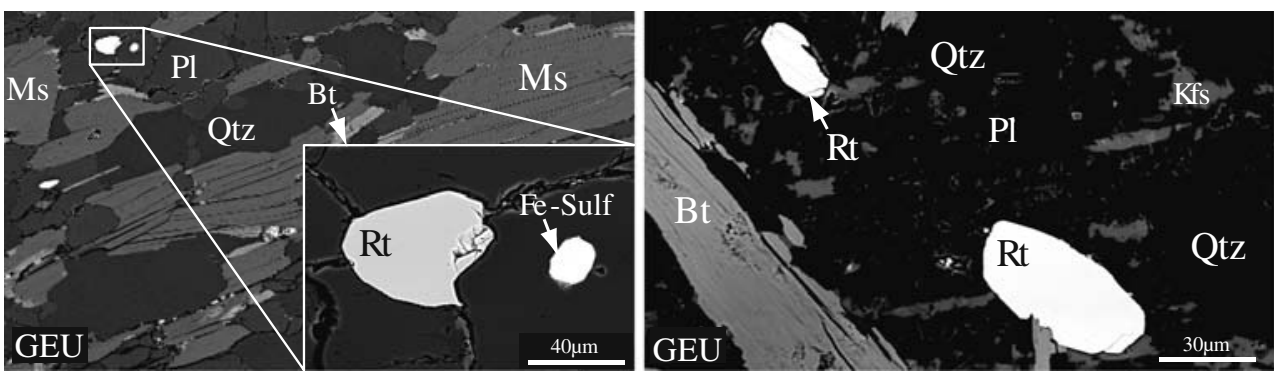

one rutile grain with $\mathrm{Zr}$ concentration of $390 \mathrm{ppm}$ from the quartzite sample (Fig. 3a).

Only few rutiles from the higher-grade samples (EGB04R11e, A15c) have Zr contents below the EMP detection limit. $\mathrm{Zr}$ contents obtained through SIMS and EMP are in
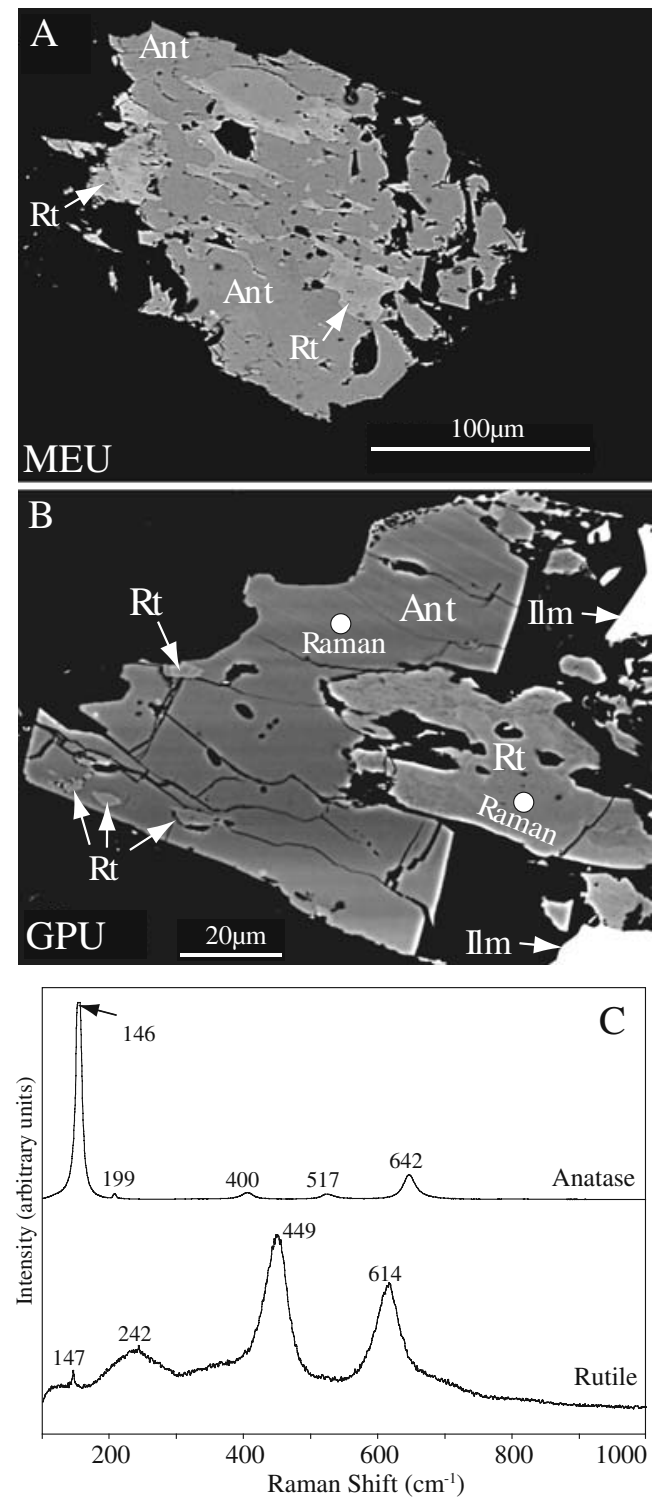

Fig. 5 a and b: High-contrast BSE images showing rutile coexisting with anatase. Notice that rutile is brighter. $\mathbf{c}$ Raman spectra of anatase and rutile (spot location presented in $\mathrm{B}$ ) agreement with mineral assemblage and metamorphic textures observed in these rocks with $\mathrm{Zr}$ concentrations up to $200 \mathrm{ppm}$ for sample A15, corresponding to temperatures of ca. $630^{\circ} \mathrm{C}$.

We would like to note that highest $\mathrm{Zr}$ contents in rutiles from garnet bearing rocks are usually obtained for rutiles included in garnet (see also discussion in Triebold et al. 2007).

\section{Discussion}

Behavior of $\mathrm{Nb}$ during rutile formation from ilmenite

Samples from the GPU and MEU record intermediate stages of a reaction where rutile is forming from ilmenite breakdown. The prograde evolution of this reaction can be summarized by the simplified model presented in Fig. 8 and can be described as follows: Initially, only ilmenite occurs and hosts the main portion of $\mathrm{Nb}$ and $\mathrm{Ti}$ of the whole rock (WR). Under metamorphic conditions of the GPU $\left(\sim 480^{\circ} \mathrm{C}\right.$, 0.6-0.9 GPa) rutile starts to grow associated with the breakdown of ilmenite. With increasing metamorphic grade, the reaction progresses and the rutile/ilmenite ratio increases. In these intermediate stages rutiles occur as polycrystalline aggregates inside the volume previously occupied by ilmenite. $\mathrm{Nb}$ is distributed between both phases. The excess $\mathrm{Fe}$ is used to crystallize chlorite, with other elements available in the surrounding silicates. At higher metamorphic grade, rutile is the only Ti-phase and consequently the main carrier of $\mathrm{Nb}$ and $\mathrm{Ti}$. It is coarser grained as a result of re-crystallization and/or ripening and forms rounded grains (see, e.g., Fig. 4). Notice that biotite and phengite can incorporate significant amounts of $\mathrm{Ti}$ and its incoporation is temperature-dependent (Patiño Douce 1993; Henry and Guidotti, 2002; Henry et al. 2005). Hence, in rocks where rutile coexists with Ti-bearing micas, rutile may not have the $\mathrm{WR} \mathrm{Nb/Ta}$ ratio.

A distinct geochemical signature is observed in rutiles formed from biotite breakdown in felsic granulites from the Ivrea-Verbano Zone (Luvizotto and Zack 2009). In these rocks, $\mathrm{Nb}$ concentrations in rutiles from lowest-grade samples $\left(\mathrm{ca} .850^{\circ} \mathrm{C}\right.$ ) show a larger spread when compared 

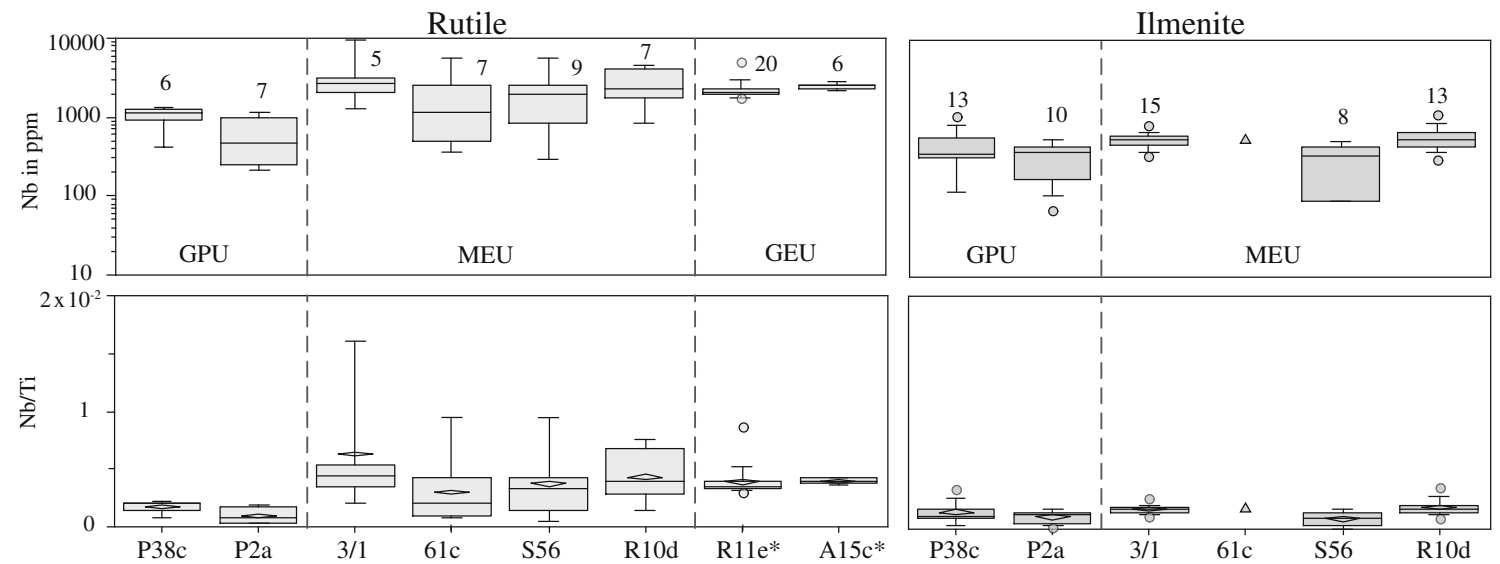

Fig. 6 Summary of Nb concentrations (EMP and SIMS) obtained for the rutiles and ilmenites. Samples are sorted according to increasing metamorphic grade. The boxes represent, from bottom to top, the second and third quartile ( 25 and $75 \%$ of the population). The bar inside the box represents the median, while the lozenge (just for $\mathrm{Nb}$ / Ti) represents the average. Whiskers represent the 10th and the 90th

to those from higher grades (up to $930^{\circ} \mathrm{C}$ ). According to the authors, this behavior can be predicted assuming inter-grain diffusion of $\mathrm{Nb}$ during continuous crystallization of rutile from biotite and considering that rutile strongly favors $\mathrm{Nb}$ over $\mathrm{Ti}$ when compared with biotite $\left({ }^{\mathrm{Nb} / \mathrm{Ti})} \mathrm{Rt} /{ }^{(\mathrm{Nb} / \mathrm{Ti})} \mathrm{Bt}\right.$ ratio is ca. 50, see discussion in Luvizotto and Zack 2009).

Klemme et al. $(2005,2006)$ presented experimentally derived rutile/melt and ilmenite/melt partition coefficients for several elements, including $\mathrm{Nb}$. The experiments were carried out at atmospheric pressure and temperatures ranging from 1200 to $1300^{\circ} \mathrm{C}$. Results confirm previously obtained data (e.g., Green and Pearson 1987; Foley et al. 2000; Green 2000; Horng and Hess 2000; Schmidt et al. 2004) and show that $\mathrm{Nb}$ is strongly compatible in rutile $\left(D_{N b}^{R t / m e l t}=22\right.$ for andesitic melt composition) and moderately compatible to incompatible in ilmenite $\left(D_{N b}^{I l m / m e l t}=0.88-1.9\right.$ for basaltic and $D_{N b}^{I l m}=0.55$ for basaltic andesite melt compositions). These data show that rutile strongly favors the incorporation of $\mathrm{Nb}$ when compared with ilmenite (assuming similar partitioning behavior for the andesitic and basaltic andesite melt composition). In fact, using these partition coefficients $\mathrm{a}^{(\mathrm{Nb} / \mathrm{Ti})} \mathrm{Rt} /{ }^{(\mathrm{Nb} / \mathrm{Ti})} \mathrm{Ilm}$ ratio of ca. 50 can be calculated. This value is identical to the one calculated by Luvizotto and Zack (2009) for the rutile/biotite pair. Hence, the same Nb behavior described by the authors is expected to be observed in the studied rocks (i.e., rutiles coexisting in chemical equilibrium with ilmenite are expected to have significantly higher $\mathrm{Nb} / \mathrm{Ti}$ ratios). As $\mathrm{Nb}$ is strongly more compatible in rutile than in ilmenite, rutiles formed during early stages of the reaction are expected to have $\mathrm{Nb}$ contents significantly higher than the ilmenite. As the reaction continues, $\mathrm{Nb}$ concentrations in both rutile and ilmenite decrease strongly. Calculations carried out by Luvizotto and Zack (2009) show percentile. When they occur, outliers are represented by small circles. Numbers above the boxes refer to the number of analyzed grains (one spot per grain). As EMP and SIMS results are within error, for grains analyzed by both techniques only EMP data is plotted (because of the higher spatial resolution). *: ilmenite-free samples

that during the initial stages of the reaction the decrease of only $3 \%$ in the modal proportion of biotite leads to a reduction of one order of magnitude in the $\mathrm{Nb}$ concentration of both rutile and biotite. Such large variations are also expected to be recorded in rutiles formed from ilmenite breakdown.

Niobium concentration data presented in Fig. 6 show that rutiles from the MEU display the highest variations in $\mathrm{Nb}$ content among all the studied samples. Furthermore, they have $\mathrm{Nb} / \mathrm{Ti}$ ratios significantly higher than ilmenite (up to $\sim 15$ times in sample 3/1). According to the partition coefficients presented above, the $\mathrm{Nb}$ behavior in rutiles from these samples is consistent with rutile crystallization in equilibrium with ilmenite. The highest $\mathrm{Nb}$ concentration obtained for a rutile from sample 3/1 (9526 ppm) is consistent with a rutile occurring in equilibrium with an ilmenite containing $\sim 100 \mathrm{ppm}$ of $\mathrm{Nb}$. Hence, our results support that $\mathrm{Nb}$ locally mobilized and is able to equilibrate between rutile and ilmenite under the metamorphic conditions of the MEU.

Rutiles from the GEU rocks are ilmenite-free. We interpret the absence of ilmenite as an indication that the rutile forming reaction was completed. Rutiles from these rocks show a small spread in $\mathrm{Nb}$ concentrations. Assuming the analyzed samples to be representative, the data suggest homogenization of the variable $\mathrm{Nb}$ contents generated during the early stages of rutile crystallization. Such homogenization can take place through mechanisms like dynamic recrystallization and/or inter-grain diffusion, in accordance with the observation of Luvizotto and Zack (2009). These processes are facilitated by higher temperatures and therefore more probable to take place in rocks from the GEU than in those from the GPU and MEU. 
Fig. 7 Summary of $\mathrm{Zr}$ concentrations (EMP and SIMS) obtained for the studied rutiles. Temperatures (on the top of the diagrams) were calculated after the calibration of Tomkins et al. (2007) for pressure values within $0.9-1.2 \mathrm{GPa}$ (differences in temperature related to the pressure effect are minimal within this pressure interval and are not representable on the scale of the diagrams)

Exceptions to the $\mathrm{Nb}$ behavior discussed above are samples from the lower grade GPU. Rutiles from this unit are characterized by small scatter in $\mathrm{Nb}$ content and by $\mathrm{Nb} / \mathrm{Ti}$ ratios close to the ones obtained for ilmenites. Results indicate that these rutiles are not in chemical equilibrium with ilmenite (higher $\mathrm{Nb} / \mathrm{Ti}$ ratios in rutile are expected). One possible interpretation is that at metamorphic conditions of the GPU (ca. $480^{\circ} \mathrm{C}$ and $<0.9 \mathrm{GPa}$ ) chemical diffusion was too slow and $\mathrm{Nb}$ was not able to exchange between rutile and ilmenite. This observation suggests that temperature is one of the main factors controlling the $\mathrm{Nb}$ behavior, i.e., chemical mobility. However, other variables such as presence of fluids and slow cooling rates may favor the mobility of $\mathrm{Nb}$ as well.

Temperature records in rutile from medium-grade metasedimentary rocks

The textures observed in metasedimentary rocks from the GPU indicate that rutile crystallization took place under $P T$ conditions of ca. $480^{\circ} \mathrm{C}$ and $0.6-0.9 \mathrm{GPa}$. Zr concentrations obtained for rutiles from this unit (Fig. 7) confirm previous geothermometric data as all EMP measurements were below detection limit $\left(<40 \mathrm{ppm}\right.$ of $\left.\mathrm{Zr},<500^{\circ} \mathrm{C}\right)$. All but one rutile from the $\mathrm{MEU}$ rocks give temperatures that match the thermobarometric literature data $\left(500-560^{\circ} \mathrm{C}\right.$, Rötzler et al. 1998). Temperatures in the $560-680^{\circ} \mathrm{C}$ range are obtained for rutiles from the two investigated samples from the GEU and are consistent with peak mineral assemblages (garnet plus biotite, Table 1) and metamorphic textures observed in these rocks. None of the metamorphically-grown rutiles record unrealistically high temperatures (i.e., high $\mathrm{Zr}$ contents) and are therefore consistent with metamorphic condition under which they were formed. Low temperatures obtained for some rutiles may either be a record of an early stage during the prograde path or re-equilibration during the retrograde path.

Detrital rutiles from medium-grade metasedimentary rocks

Triebold et al. (2007) showed that several rutiles from present day drainage sediments from the catchment area of PU, GPU and MEU record temperatures up to ca. $1000^{\circ} \mathrm{C}$ (Zr-in-rutile, after calibration of Zack et al. 2004b). Since the sediments are derived from medium-grade metamorphic rocks (max. Tof ca. $600^{\circ} \mathrm{C}$ for the MEU-see Fig. 1), these high- $T$ rutiles are interpreted to be inherited detrital grains
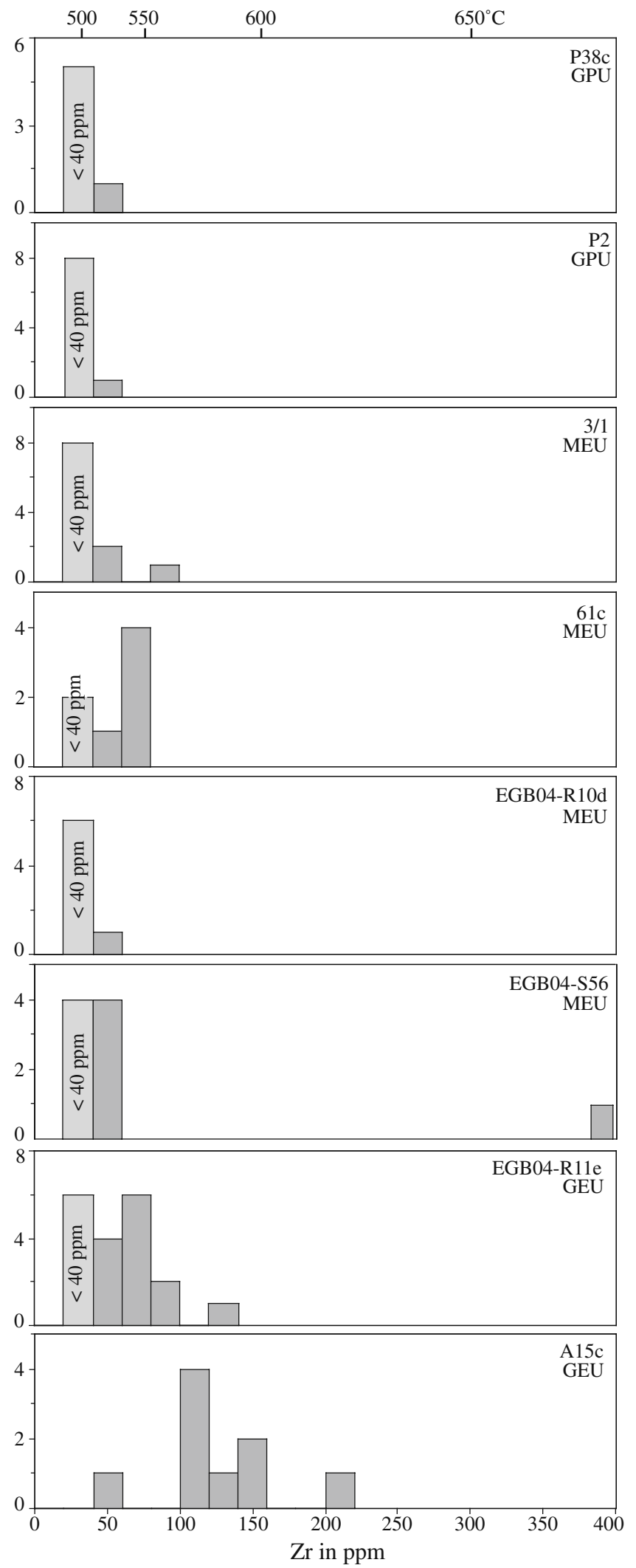


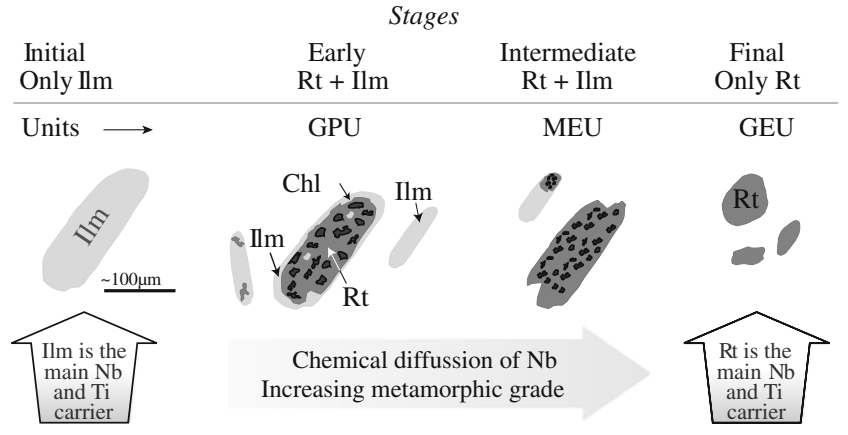

Fig. 8 Illustration showing the main stages of rutile crystallization from ilmenite during prograde metamorphism

that are preserved in these rocks. High temperatures registered by these grains are further interpreted to be records of former metamorphic cycles seen by the source rocks for the sediments that compose the present-day metasedimentary rocks of the PU, GPU and MEU. Such high- $T$ rutiles are not found in the catchment area of the GEU. Based on these observations, the authors concluded that the complete reequilibration of $\mathrm{Zr}$ contents in inherited detrital rutile grains takes place only above ca. $600^{\circ} \mathrm{C}$. The existence of a minimum reequilibration temperature has also been discussed by other authors (Stendal et al. 2006; Meinhold et al. 2008).

Triebold et al. (2007) observed a high frequency of high$T$ rutiles (and hence inherited detrital rutiles) in a mineral separate from a quartzite sample from the MEU (EGB04S56, the same investigated in this paper). Such observation contradicts results showing that highest frequencies of high$T$ rutiles are observed in sediments derived from the PU and GPU, thus raising the hypothesis that quartzites may be the main source of high- $T$ rutiles in present-day sediments derived from greenschist-facies metassediments that contain quartzite. This hypothesis is based on the fact that quartzites are less reactive when comparing to other metamorphic rocks, as the lack of $\mathrm{Ca}$ - and Fe-bearing phases reduces their ability to crystallize titanite and ilmenite under conditions where rutile is not stable (e.g., greenschist facies). The downside of using mineral separates is that petrographic textures are not preserved. Here, we present BSE images from the quartzite sample (Fig. 3) showing how these inherited rutiles occur in the rock. They are clearly distinguishable from the polycrystalline aggregate that represent the newly formed rutiles, since they occur as large single crystals surrounded by fine grain ilmenite (interpreted to be formed during prograde metamorphism under green-schist facies or below). In addition, inherited rutiles have much higher $\mathrm{Nb}$ and $\mathrm{Zr}$ contents (up to 3900 and 390 ppm respectively, see data in Fig. 3).

The results show, therefore, that quartzites may preserve size and chemical composition of inherited detrital rutiles up to higher metamorphic conditions when compared to pelitic rocks. Preliminary calculations were carried out to evaluate the impact of our observations for the sediment record of rutile. More specifically, we evaluate which rock type liberates/ delivers the highest amount of detrital rutile during erosion of a greenschist-facies metasedimentary catchment. We focus here on sand-sized grains, because rutile in provenance studies is mostly related to heavy mineral analyses, which usually concentrates on the finer-grained sand fraction. Based on BSE images (see, e.g., Figs. 2 and 7) and petrographic observation, average rutile grain sizes (size of the smallest dimension) of $50 \mu \mathrm{m}$ and $100 \mu \mathrm{m}$ can be roughly estimated for the metapelites (phyllites/schists) and quartzites, respectively.

Calculations were performed assuming a Gaussian grain size distribution and a standard deviation of $20 \%$ (in accordance with results obtained for garnet porphyroblasts by Hirsch 2008). Probabilities of occurrence of rutiles in metapelites and quartzites were calculated for three grain size fractions (Table 2): $63 \mu \mathrm{m}$, which corresponds to the silt-sand threshold, a fraction used in traditional heavy mineral analyses (see, e.g., Weltje and von Eynatten 2004); $80 \mu \mathrm{m}$, grain size fraction employed in our quantitative provenance studies of rutile (see von Eynatten et al. 2005; Triebold et al. 2007) and $100 \mu \mathrm{m}$, the average rutile

Table 2 Probabilities of occurrence of rutiles with grains sizes of 63,80 and $100 \mu \mathrm{m}$ in metapelites and quartzites; and percentage contribution of quartzites in the sedimentary record of rutiles from low- to medium-grade metasedimentary sequences

\begin{tabular}{lcccccc}
\hline Rutile & Prob. & Prob. & \multicolumn{2}{c}{ Prob. Ratio } & \multicolumn{2}{c}{ Percentage contrib. in sediment } \\
\cline { 5 - 7 } Fraction & Mpel(\%) & Qzt(\%) & Qzt/Mpel (vol.) & 1\% Qzt & \%5 Qzt & $10 \%$ Qzt \\
\hline $63 \mu \mathrm{m}$ & 10 & 96 & 0.6 & 0.6 & 3.0 & 100 \\
$80 \mu \mathrm{m}$ & 0.14 & 84 & 38 & 100 & 100 & 100 \\
$100 \mu \mathrm{m}$ & $<0.003$ & 50 & $>1000$ & & 100 \\
\hline
\end{tabular}

Parameters: Metapelite $(\mathrm{Mpel})$-average grain size $=50 \mu \mathrm{m}$, standard deviation $=20 \%, \mathrm{TiO}_{2}$ (whole rock) $1.0 \%$. Quartzite $($ Qzt)-average grain size $=$ $100 \mu \mathrm{m}$, standard deviation $=20 \%, \mathrm{TiO}_{2}$ (whole rock) $0.5 \%$. Prob (\%)-probability of occurrence of rutile (calculated assuming a Gaussian distribution). Please notice that the probability ratio of quartzite/pelite is expressed in volume (calculated taking into account the probabilities, the differences in grain sizes (converted to volume) and $\mathrm{TiO}_{2}$ contents in the whole rock) 
diameter in the quartzite, which relates via hydrodynamic equivalence to a typical fine- to medium-grained sand sample of average grain size $\sim 200 \mu \mathrm{m}$. According to our results, in a catchment area with a quartzite volume of $1.0 \%, 38 \%$ of the rutile grains larger than $80 \mu \mathrm{m}$ would derive from the quartzite. With a volume of 2.5 to $3.0 \%$ quartzite, almost all rutile grains larger than $80 \mu \mathrm{m}$ would come from this rock. For the $100 \mu \mathrm{m}$ fraction the effect is even more pronounced, as quartzites would virtually be the only source of rutile, even for quartzite abundances below $1.0 \%$. On the other hand, results show that pelites would still be the main contributor of rutile for the $63 \mu \mathrm{m}$ fraction.

Textures and trace element data presented above show that quartzites may preserve detrital rutile grains (i.e., clastic grains associated with the sedimentary deposition of the protolith) up to temperatures higher than those needed to crystallize new rutiles in metapelitic rocks. Furthermore, these detrital grains may record information (e.g., $\mathrm{Nb}$ and $\mathrm{Cr}$ systematics and $T$ ) inherited from an earlier geological cycle. This observation, combined with the calculations presented above, suggests that sand-sized rutiles derived from greenschit-facies metasedimentary sequences that also contain quartzites may not provide information on the metapelites, since small volumes of quartzite may dominate the sedimentary record of rutile (see Table 2).

\section{Conclusions}

Textures and trace element data indicate rutile growth from ilmenite in medium-grade metasedimentary rocks from the Erzgebirge. In samples from the GPU rutiles occur as polycrystalline aggregates and pseudomorph the shape and $\mathrm{Nb} / \mathrm{Ti}$ of ilmenite. In MEU rocks, rutile aggregates have the shape inherited from ilmenite. However, rutiles from this unit display a larger scatter in $\mathrm{Nb}$ concentrations and have higher $\mathrm{Nb} / \mathrm{Ti}$ than ilmenite. This behavior indicates that $\mathrm{Nb}$ concentrations in rutile are evolving towards equilibration with relict ilmenites (considering that rutile strongly favors the incorporation of $\mathrm{Nb}$ when compared with ilmenite). GEU rocks are ilmenite-free. Taking into account that pelitic rocks from the studied units have similar protoliths (Mingram 1998) and assuming that they followed a rather similar prograde path, the absence of ilmenite in GEU rocks indicate that the rutile forming reaction was completed. Rutiles from these rocks show a narrow scatter in $\mathrm{Nb}$ contents, are single crystals and do not have the elongated shape inherited from ilmenite. In these rocks, the homogenization of $\mathrm{Nb}$ contents in rutile was facilitated by higher temperature and is probably related with mechanisms like dynamic recrystalization and/or inter-grain diffusion.

Temperature records on all but one rutile grain are in accordance with peak metamorphic conditions previously presented for the studied rocks. Rutiles from the GPU give temperatures $<500^{\circ} \mathrm{C}$. Temperatures within $500-560^{\circ} \mathrm{C}$ and $520-630^{\circ} \mathrm{C}$ were obtained for rutiles from MEU and GEU rocks, respectively.

The only rutile with an exceptionally high $\mathrm{Zr}$ content (390 ppm, $\mathrm{T}=680^{\circ} \mathrm{C}$ ) is from a quartzite from the MEU. This grain is interpreted to be an inherited detrital relict. Due to the lack of Fe- Ca-bearing phases, quartzites are less reactive than other rock types (e.g., phyllites and schists). This strongly decreases the ability to form ilmenite and/or titanite.

Phyllites and schists are low- to medium-grade metamorphic products of pelitic sediments (fine-grained clastic sediments of less than $1 / 16 \mathrm{~mm}$ grain size; Pettijohn 1975). On the other hand, quartzites are often the metamorphic product of coarser grained sediments, e.g., sandstones. In the investigated phyllites and schists, metamorphicallygrown rutiles are fine-grained (smaller axis $<50 \mu \mathrm{m}$ ) and occur as polycrystalline aggregates (easily disintegrated during weathering and mechanical transport in sediments). However, large detrital rutile grains inherited from a previous cycle may still be preserved in the quartzites. Preliminary calculations taking into account modal abundance and grain size distribution of rutile in metapelites and quartzites show that quartzites may often be the main source for rutiles in sediments derived from low-grade metamorphic rocks. This seem to be the case of the Erzgebirge, where high-temperature rutile relicts are frequently found in sediments derived from low- to mediumgrade rocks, even though the volume of quartzite is less than $5 \%$. If such interpretation is correct, these hightemperature relicts pre-date the peak metamorphism achieved by Erzgebirge rocks. It has indeed been discussed by Triebold et al. (2007) that these high-temperature rutiles fit into the common picture of a derivation of Early Paleozoic sediment of central Europe from source rocks from the West African Craton. Our observations thus encourage further studies, e.g., U-Pb dating of these hightemperature relicts.

Acknowledgements The manuscript benefitted from constructive reviews of Bernard Bingen and Andreas Moeller. Timm John and Fred Gaidies are thanked for inviting us to contribute to this special issue. Birgit Plessen (née Mingram) is thanked for providing part of the samples investigated in the paper. Hans-Peter Meyer and Thomas Ludwig are thanked for the maintenance of the EMP and SIMS (respectively) at the Universität Heidelberg and for their assistance during analyses. Burkhard Schmidt is thanked for his assistence during Raman analyses at the Universitat Göttingen. Renato de Moraes is thanked for fruitful discussions. Mauly Bottene is thanked for improving the English style and grammar of the manuscript. This project was financially supported by the Deutsche Forschungsgemeinschaft (projects ZA 285/2 and EY 23/3).

Open Access This article is distributed under the terms of the Creative Commons Attribution Noncommercial License which permits any noncommercial use, distribution, and reproduction in any medium, provided the original author(s) and source are credited. 


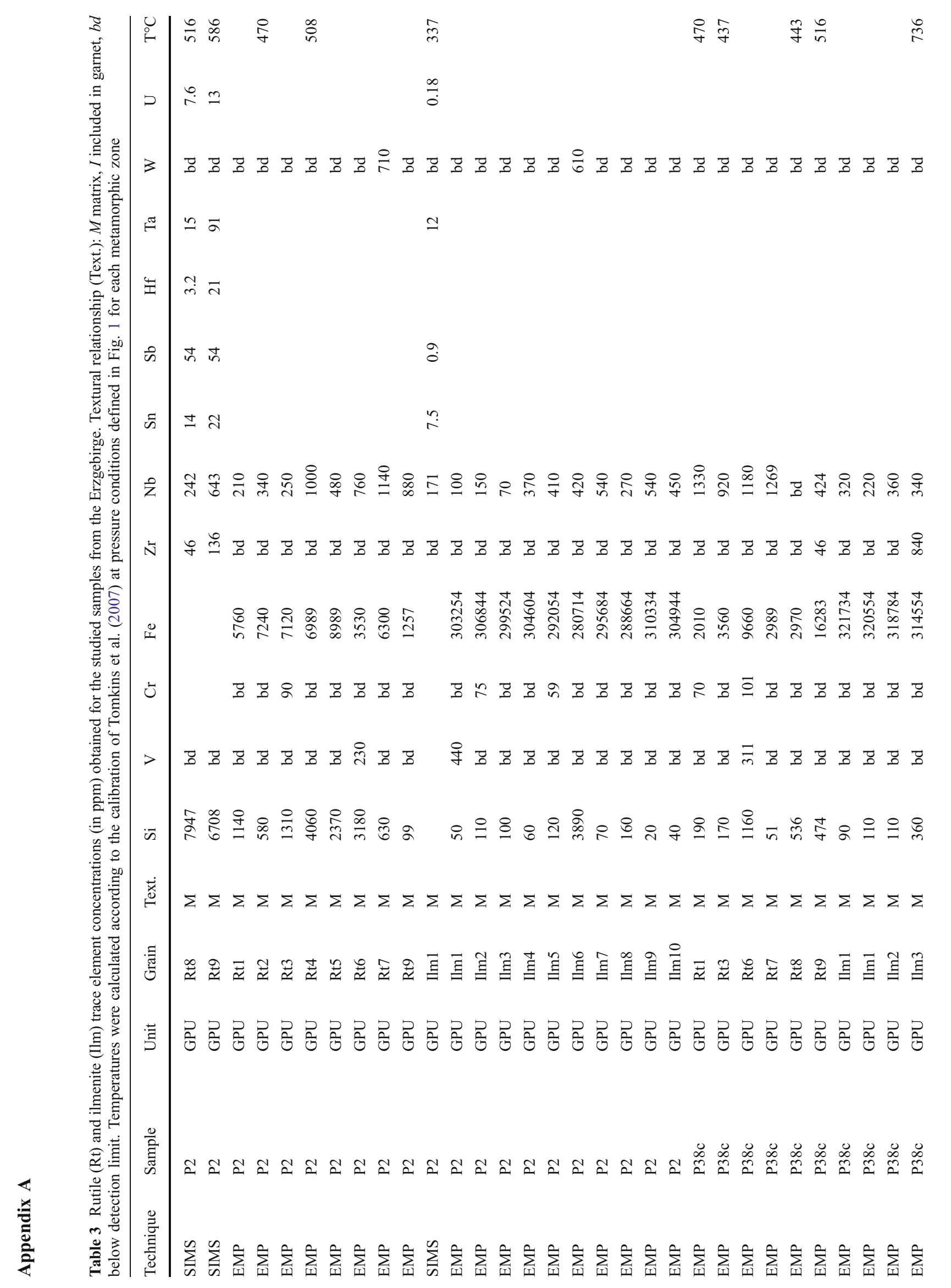




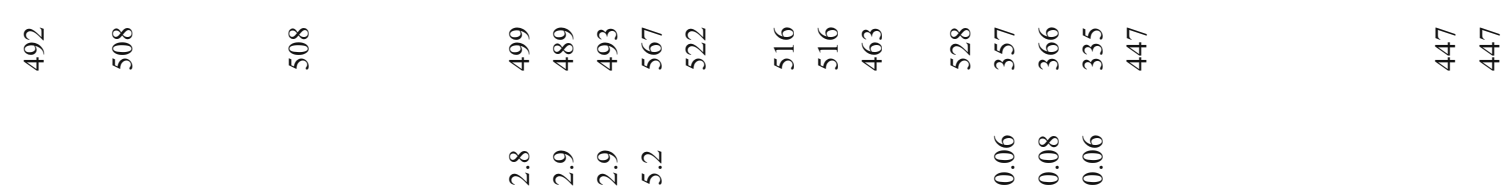

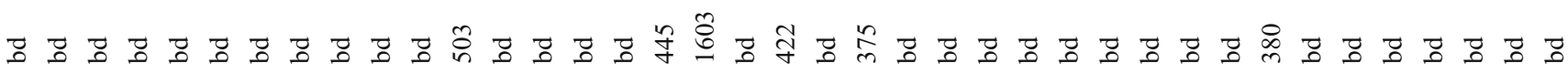

$$
\begin{aligned}
& \stackrel{\Xi}{\Xi} \bar{\infty} \quad \quad \quad \backsim \infty \\
& \stackrel{-\rightarrow}{\infty} \stackrel{\infty}{\infty} \stackrel{\infty}{+\infty}
\end{aligned}
$$

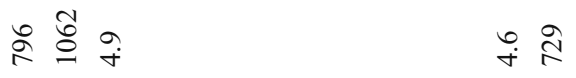

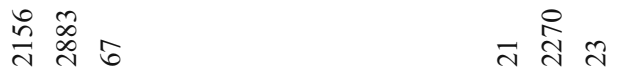

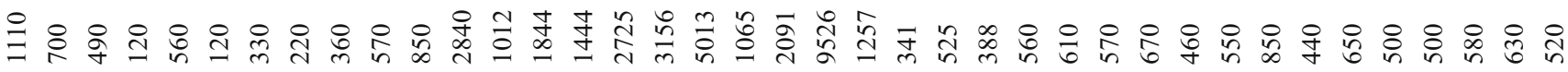
롤

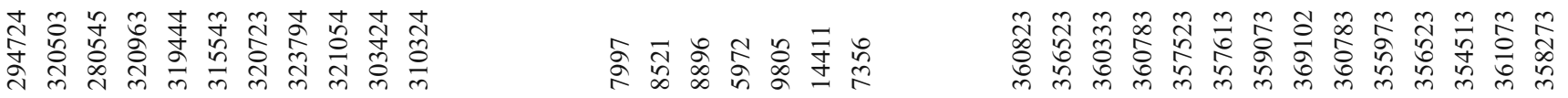

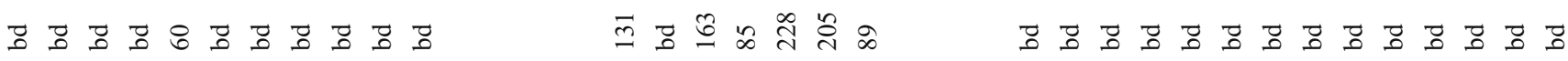
च

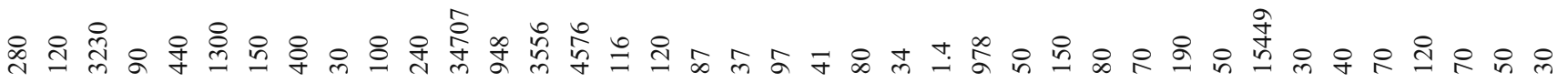

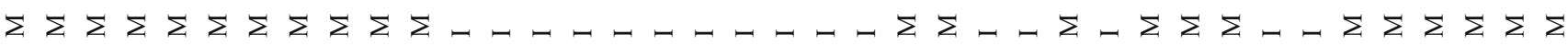

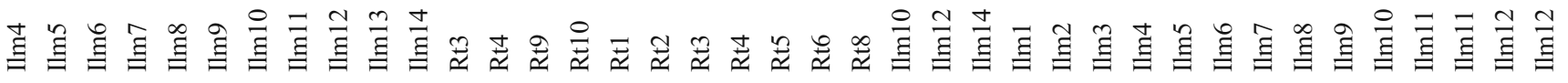

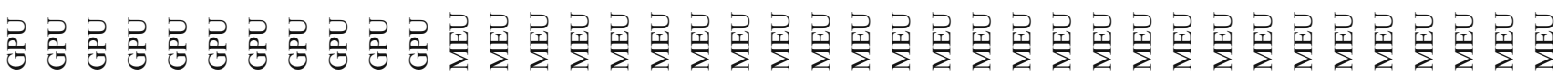

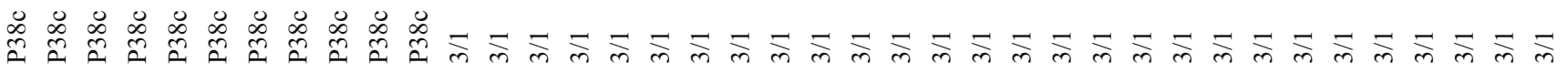

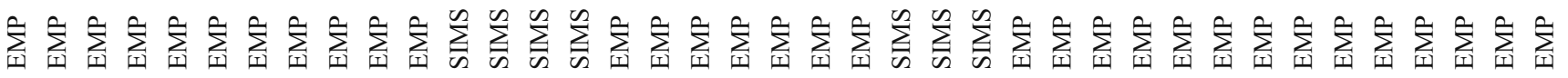




\begin{tabular}{|c|c|c|c|}
\hline 㟶 & 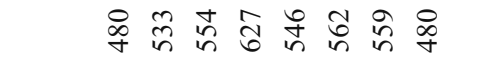 & 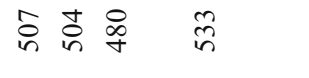 & in $\quad$ 表 \\
\hline D & & $\stackrel{+}{\dot{\leftrightarrow}} \stackrel{+}{+}$ & ț \\
\hline 3 & 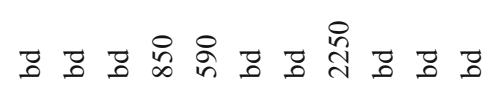 & 串 ఫू。 & 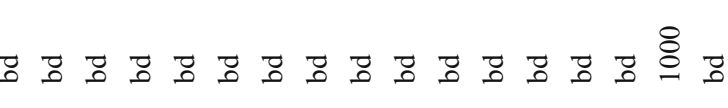 \\
\hline$\approx$ & & $\stackrel{2}{\circ} \stackrel{4}{\circ}$ & 12 \\
\hline 出 & & $\vec{i} \stackrel{i}{ }$ & 용. \\
\hline के & & $I_{\infty} \mathbb{x}$ & $\stackrel{0}{0}$ \\
\hline की & & के के & $\simeq \simeq$ \\
\hline $\bar{z}$ & 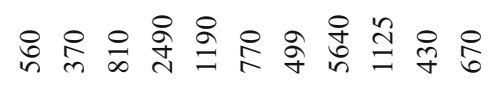 & 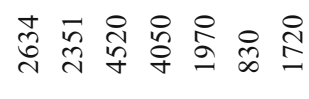 & 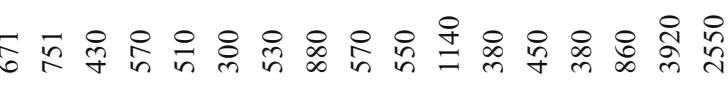 \\
\hline$\dot{N}$ & 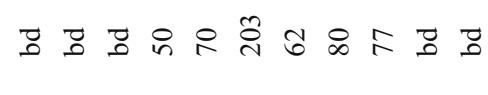 & 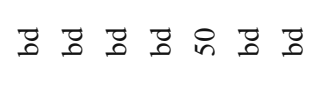 & 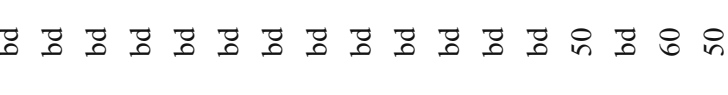 \\
\hline i & 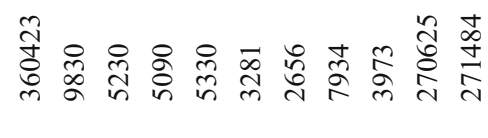 & 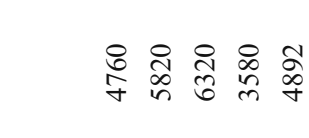 & 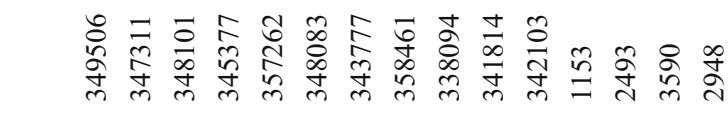 \\
\hline ¿ & 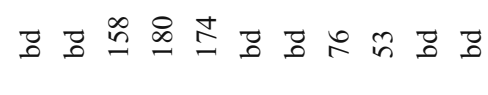 & in $\stackrel{\circ}{\circ}$ 零 $]$ & 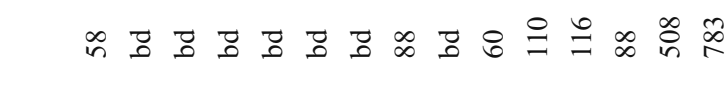 \\
\hline$>$ & 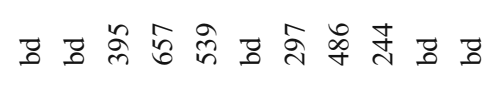 & $\vec{\Phi} \bar{\infty} \bar{\infty} \vec{D}]$ & 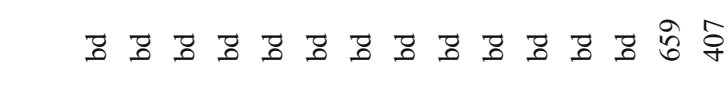 \\
\hline is & 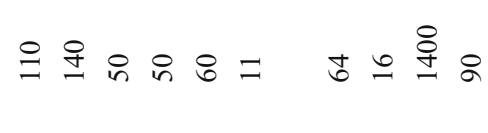 & 웅ㅇํํํㅇ & 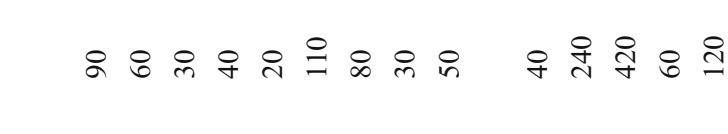 \\
\hline 离 & $\Sigma \neg-\neg-\neg-\neg \Sigma \Sigma$ & $\Sigma \Sigma-r-r \Sigma$ & 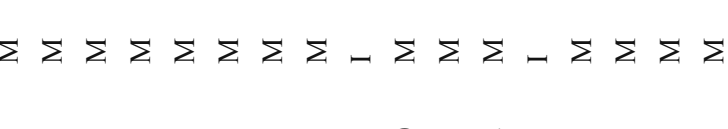 \\
\hline 瓷 & 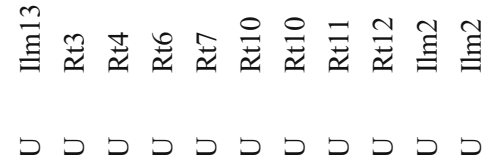 & 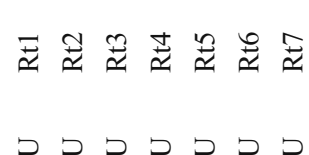 & 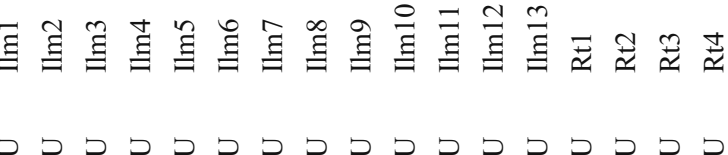 \\
\hline 蒙 & 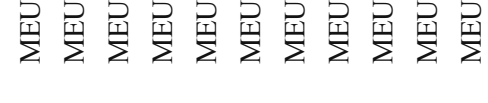 & & 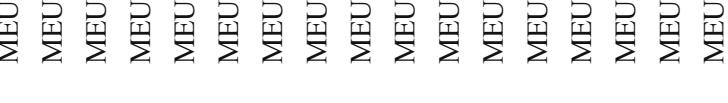 \\
\hline 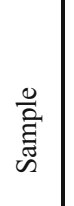 & $-\frac{0}{6}$ & 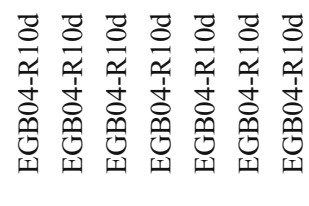 & 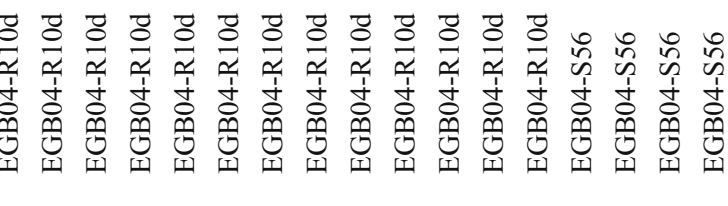 \\
\hline 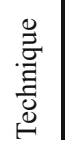 & & & \\
\hline
\end{tabular}


\& 声

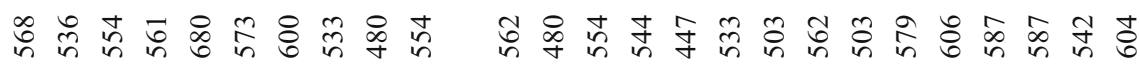

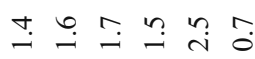

$\stackrel{\infty}{\dot{0}} \stackrel{8}{+}$

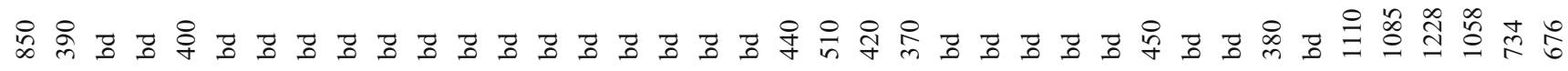

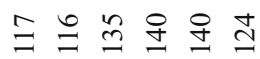

$$
\begin{aligned}
& \text { ㄱํำ }
\end{aligned}
$$

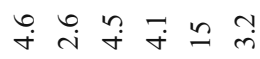

$$
\begin{aligned}
& \underset{i n}{\infty}= \\
& \text { 的学的字褔 }
\end{aligned}
$$

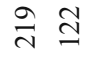

$$
\begin{aligned}
& \Xi \sigma \stackrel{\infty}{=} \sigma \alpha \stackrel{\infty}{\circ}
\end{aligned}
$$

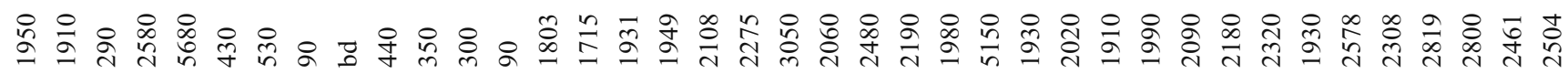

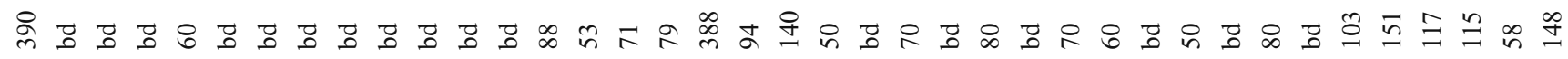

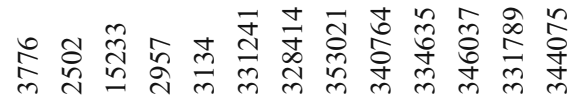

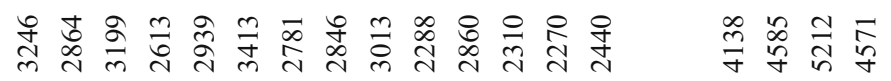

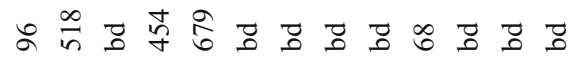

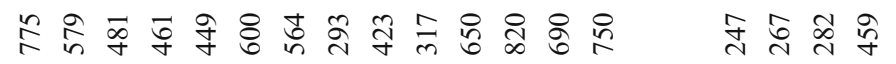

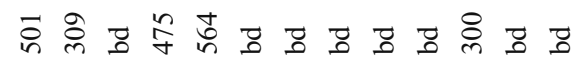

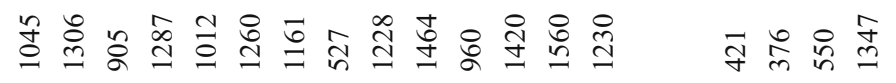

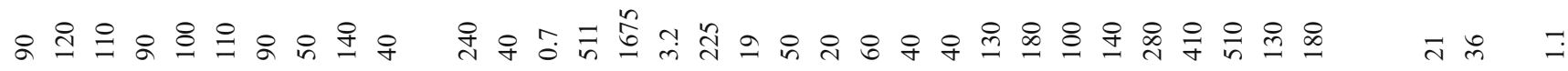

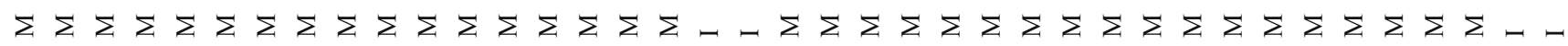

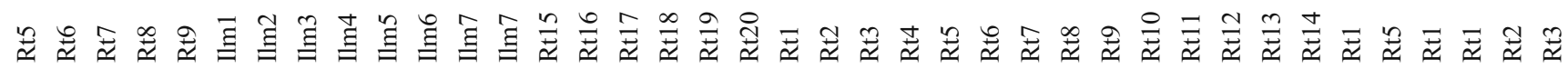

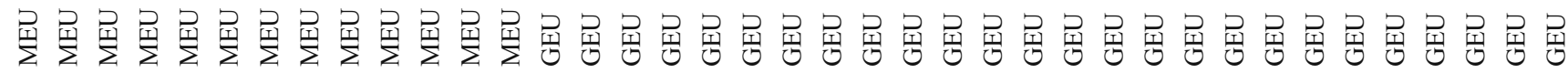

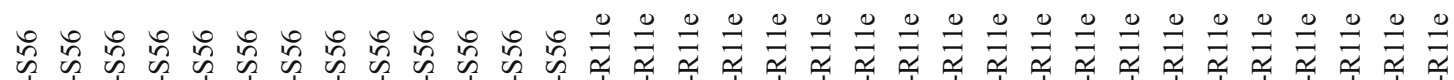

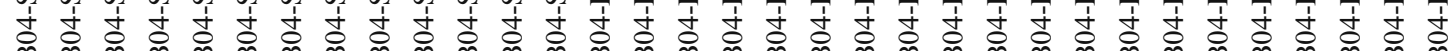

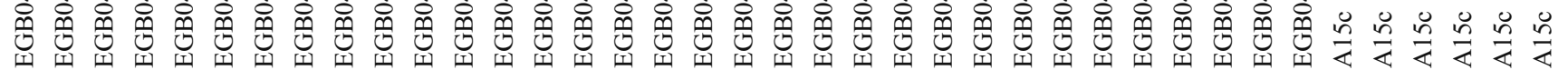

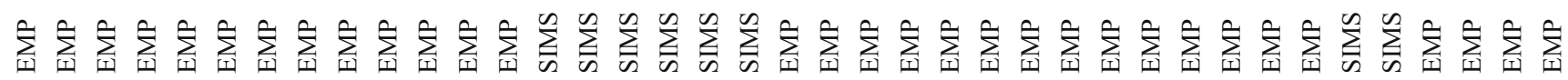




\section{References}

Brenan JM, Shaw HF, Phinney DL, Ryerson FJ (1994) Rutile-aqueous fluid partitioning of $\mathrm{Nb}, \mathrm{Ta}, \mathrm{Hf}, \mathrm{Zr}, \mathrm{U}$ and $\mathrm{Th}$ : implications for high field strength element depletions in island-arc basalts. Earth Planet Sci Lett 128:327-339

Foley SF, Barth MG, Jenner GA (2000) Rutile/melt partition coefficients for trace elements and an assessment of the influence of rutile on the trace element characteristics of subduction zone magmas. Geochim Cosmochim Acta 64:933938

Green TH (2000) New partition coefficient determinations pertinent to hydrous melting processes in subduction zones. In: Davidson JA J P Gamble, Price RC (eds) States of the arc 2000: Processes and timescales. Wellington, pp 92-95

Green TH, Pearson NJ (1987) An experimental-study of $\mathrm{Nb}$ and $\mathrm{Ta}$ partitioning between Ti-rich minerals and silicate liquids at highpressure and temperature. Geochim Cosmochim Acta 51:55-62

Harley SL (2008) Refining the P-T records of UHT crustal metamorphism. J Metamorph Geol 26:125-154

Henry DJ, Guidotti CV (2002) Titanium in biotite from metapelitic rocks: temperature effects, crystal-chemical controls, and petrologic applications. Am Mineral 87:375-382

Henry DJ, Guidotti CV, Thomson JA (2005) The Ti-saturation surface for low-to-medium pressure metapelitic biotites: implications for geothermometry and Ti-substitution mechanisms. Am Mineral 90:316-328

Hirsch D (2008) Controls on porphyroblast size along a regional metamorphic field gradient. Contrib Mineral Petrol 155:401-415

Horng WS, Hess PC (2000) Partition coefficients of $\mathrm{Nb}$ and $\mathrm{Ta}$ between rutile and anhydrous haplogranite melts. Contrib Mineral Petrol 138:176-185

Klemme S, Prowatke S, Hametner K, Günther D (2005) Partitioning of trace elements between rutile and silicate melts: implications for subduction zones. Geochim Cosmochim Acta 69:2361-2371

Klemme S, Günther D, Hametner K, Prowatke S, Zack T (2006) The partitioning of trace elements between ilmenite, ulvospinel, armalcolite and silicate melts with implications for the early differentiation of the Moon. Chem Geol 234:251-263

Kretz R (1983) Symbols for rock forming minerals. Am Mineral 68:277-279

Luvizotto GL, Zack $\mathrm{T}$ (2009) $\mathrm{Nb}$ and $\mathrm{Zr}$ behavior in rutile during high-grade metamorphism and retrogression: an example from the Ivrea-Verbano Zone. Chem Geol 261:303-317

Luvizotto G, Zack T, Meyer H, Ludwig T, Triebold S, Kronz A, Münker C, Stockli D, Prowatke S, Klemme S, Jacob DE, von Eynatten H (2009) Rutile crystals as potential secondary standards for microanalysis. Chem Geol 261:346-369

McDonough WF (1991) Partial melting of subducted oceanic crust and isolation of its residual eclogitic lithology. Philos Trans R Soc London, Ser A 335:407-418

Meinhold G, Anders B, Kostopoulos D, Reischmann T (2008) Rutile chemistry and thermometry as provenance indicator: an example from Chios Island, Greece. Sediment Geol 203:98-111

Mingram B (1996) Geochemische Signaturen der Metasedimente des erzgebirgischen Krustenstapels. GeoForschungsZentrum Potsdam Scientific Technical Report STR96/04 pp 1-104

Mingram B (1998) The Erzgebirge, Germany, a subducted part of northern Gondwana: geochemical evidence for repetition of early Palaeozoic metasedimentary sequences in metamorphic thrust units. Geol Mag 135:785-801

Mingram B, Rötzler K (1999) Geochemische, petrologische und geochronologische Untersuchungen im ErzgebirgskristallinRekonstruktion eines Krustenstapels. Schriftenreihe für Geologische Wissenschaften 9:80 
Münker C (1998) Nb/Ta fractionation in a Cambrian arc/back-arc system, New Zealand: source constraints and application of refined ICPMS techniques. Chem Geol 144:23-45

Patiño Douce AE (1993) Titanium substitution in biotite-an empirical model with applications to thermometry, $\mathrm{O}_{2}$ and $\mathrm{H}_{2} \mathrm{O}$ barometries, and consequences for biotite stability. Chem Geol 108:133-162

Pettijohn F (1975) Sedimentary rocks. Harper and Row, New York $628 \mathrm{pp}$

Rötzler K, Schumacher R, Maresch WV, Willner AP (1998) Characterization and geodynamic implications of contrasting metamorphic evolution in juxtaposed high-pressure units of the western Erzgebirge (Saxony, Germany). Eur J Mineral 10:261280

Rudnick RL, Barth M, Horn I, McDonough WF (2000) Rutile-bearing refractory eclogites: missing link between continents and depleted mantle. Science 287:278-281

Saunders AD, Tarney J, Weaver SD (1980) Transverse geochemical variations across the Antarctic Peninsula: implications for the genesis of calc-alkaline magmas. Earth Planet Sci Lett 46:344360

Schmidt MW, Dardon A, Chazot G, Vannucci R (2004) The dependence of $\mathrm{Nb}$ and $\mathrm{Ta}$ rutile-melt partitioning on melt composition and $\mathrm{Nb} / \mathrm{Ta}$ fractionation during subduction processes. Earth Planet Sci Lett 226:415-432

Spear FS, Wark DA, Cheney JT, Schumacher JC, Watson EB (2006) Zr-in-rutile thermometry in blueschists from Sifnos, Greece. Contrib Mineral Petrol 152:375-385

Stalder R, Foley SF, Brey GP, Horn I (1998) Mineral-aqueous fluid partitioning of trace elements at $900-1200^{\circ} \mathrm{C}$ and $3.0-5.7 \mathrm{GPa}$ : new experimental data for garnet, clinopyroxene, and rutile, and implications for mantle metasomatism. Geochim Cosmochim Acta 62:1781-1801

Stendal H, Toteu SF, Frei R, Penaye J, Njel UO, Bassahak J, Nni J, Kankeu B, Ngako V, Hell JV (2006) Derivation of detrital rutile in the Yaounde region from the Neoproterozoic Pan-African belt in southern Cameroon (Central Africa). J Afr Earth Sci 44:443458

Tomkins HS, Powell R, Ellis DJ (2007) The pressure dependence of the zirconium-in-rutile thermometer. J Metamorph Geol 25:703713

Triebold S, von Eynatten H, Luvizotto GL, Zack T (2007) Deducing source rock lithology from detrital rutile geochemistry: an example from the Erzgebirge, Germany. Chem Geol 244:421436

von Eynatten H, Tolosana-Delgado R, Triebold S, Zack T (2005) Interactions between grain size and composition of sediments: two examples. In: Mateu-Figueiras G, Barcelo-Vidal C (eds) Proceedings CoDaWork'05-2nd Compositional Data Analysis Workshop, Universitat de Girona, Girona (Spain). Available online at: http://hdl.handle.net/10256/703

Watson EB, Wark DA, Thomas JB (2006) Crystallization thermometers for zircon and rutile. Contrib Mineral Petrol 151:413-433

Weltje G, von Eynatten H (2004) Quantitative provenance analysis of sediments: review and outlook. Sediment Geol 171:1-11

Willner AP, Rötzler K, Maresch WV (1997) Pressure-temperature and fluid evolution of quartzo-feldspathic metamorphic rocks with a relic high-pressure, granulite-facies history from the Central Erzgebirge (Saxony, Germany). J Petrol 38:307-336

Zack T, Luvizotto GL (2006) Application of rutile thermometry to eclogites. Mineral Petrol 88:69-85

Zack T, Kronz A, Foley SF, Rivers T (2002) Trace element abundances in rutiles from eclogites and associated garnet mica schists. Chem Geol 184:97-122

Zack T, von Eynatten H, Kronz A (2004a) Rutile geochemistry and its potential use in quantitative provenance studies. Sediment Geol 171(1):37-58

Zack T, Moraes R, Kronz A (2004b) Temperature dependence of Zr in rutile: empirical calibration of a rutile thermometer. Contrib Mineral Petrol 148:471-488 